\title{
An exploratory study of the effect of country-by-country reporting ambiguities on Johannesburg Stock Exchange-listed companies
}

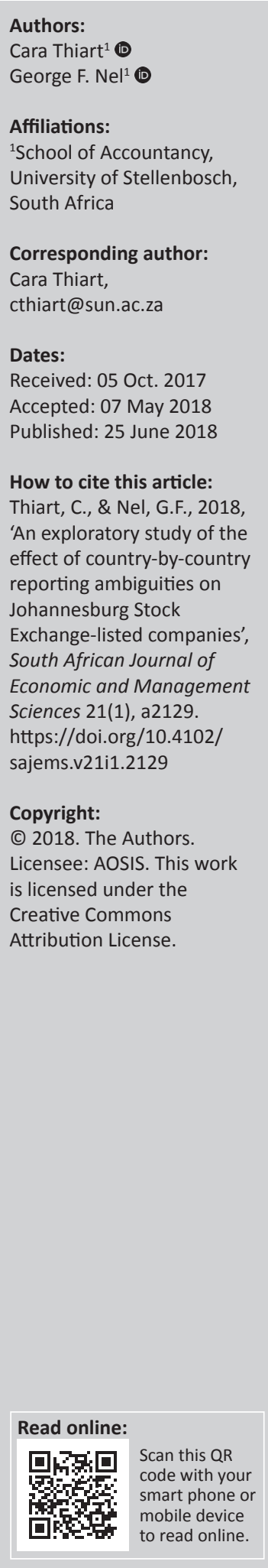

Background: South Africa issued regulations implementing country-by-country $(\mathrm{CbC})$ reporting standards for multinational enterprises (MNEs) on 23 December 2016. Country-by-country reporting will be applicable to all MNEs with a group revenue in excess of R10 billion.

Aim: The aim of the study was twofold: to identify ambiguities that might influence the filing obligation and subsequent scope of $\mathrm{CbC}$ reporting in South Africa and to quantitatively measure the potential impact of any identified ambiguities.

Setting: This study used data from Johannesburg Stock Exchange-listed companies.

Methods: The study commences with a review of the relevant regulations and other applicable literature and continues with a quantitative analysis exploring alternative interpretations deduced from this review.

Results: The review identified conflicting interpretations of how companies can be categorised as an MNE Group or not, as well as in measuring the revenue threshold. An analysis of the group structures and annual reports of a selected sample of 78 companies showed that the scope of $\mathrm{CbC}$ reporting will depend on the definitions applied to an MNE Group and revenue.

Conclusion: Further guidance is needed to determine whether non-controlling entities must be considered as Constituent Entities, as well as how to measure revenue (i.e. whether only the International Financial Reporting Standards [IFRS] 15 revenue line item should be used or whether other income should also be included).

\section{Background and introduction}

In his Budget Speech of 2017, the Finance Minister of South Africa once again emphasised that tax avoidance or evasion schemes by multinational enterprises (MNEs) should be curbed (National Treasury 2017). The Republic of South Africa (South Africa) is part of the international tax movement to eliminate base erosion and profit shifting (BEPS) through the Base Erosion and Profit-shifting Action Project of the Group of 20 (G20) and the Organisation for Economic Co-operation and Development (OECD) (The Davis Tax Committee 2014a).

The OECD/G20 BEPS Project developed 15 key reform actions in the international tax arena to ensure that profits are reported where economic activities are carried out and where economic value is created. The BEPS assists governments in closing the tax gap created by profit shifting from higher to lower or no-tax environments, without transactions having underlying economic substance (The Davis Tax Committee 2014a). The OECD published its final reports on the BEPS Project, which included the final report on BEPS Action 13, Transfer Pricing and Country-byCountry (CbC) Reporting (the final report) (OECD 2015) in October 2015.

Action 13 of the Action Plan on BEPS requires the development of rules regarding transfer pricing documentation to enhance transparency for tax administration by taking into consideration the compliance costs for businesses. The rules include a requirement that MNEs must provide all relevant governments with the required information on their global allocation of income, economic activity and taxes paid among jurisdictions (OECD 2013).

The objectives of the transfer pricing reporting documentation rules are the following:

- to ensure that taxpayers can assess their compliance with the arm's length principle

- to provide tax administrations with the information necessary to conduct an informed transfer pricing risk assessment 
- to provide tax administrations with useful information to employ in conducting an appropriately thorough transfer pricing audit (OECD 2015).

In order to achieve the above three objectives of the transfer pricing reporting documentation requirements, the OECD recommends that countries adopt a standardised approach to the compilation of transfer pricing documentation by following the suggested three-tiered structure (OECD 2015).

Such a structure should consist of:

- a master file

- a local file

- a CbC report.

The master file should provide a high-level overview of the MNE Group business. This includes information regarding the nature of its global business operations, its overall transfer pricing policies and its global allocation of income and economic activity. The master file would be available to all relevant country tax administrations. This will assist the relevant tax administrations in evaluating the presence of a significant transfer pricing risk (OECD 2015).

In contrast to the high-level overview provided by the master file, the local file should provide more detailed information, including specific intercompany transactions in each country or the jurisdiction in which the companies operate. Detailed information will consist of the identification of relevant related party transactions, the amounts involved in those transactions, and the company's analysis of the transfer pricing determinations they have made with regard to those transactions (OECD 2015).

Providing even greater detail than the local file, the purpose of the $\mathrm{CbC}$ report is to aggregate tax jurisdiction-wide, indepth information relating to the global allocation of the income, the taxes paid and certain indicators of the location of economic activity among tax jurisdictions in which the MNE Group operates. The report also requires a listing of all the constituent entities for which financial information is reported. This list includes the tax jurisdiction of incorporation, if different from the tax jurisdiction of residence, as well as the nature of the main business activities carried out by that constituent entity (OECD 2015).

Action 13 requires the reporting entity of the MNE Group to collect and file the $\mathrm{CbC}$ reporting information in its country of residence. The $\mathrm{CbC}$ report provides tax authorities with information on the global allocation of the group income and stipulates where the management functions are performed, assets are used and risks are assumed. The $\mathrm{CbC}$ report is applicable to all OECD member countries (OECD 2015).

Although South Africa is not a member country of the OECD, it was awarded OECD observer status in 2004 and is a member of the OECD BEPS Committee. South Africa has agreed to participate in the joint BEPS Action Project of the
G20 and OECD (South African Revenue Services [SARS] 2016). Furthermore, The Davis Tax Committee (2014a) noted that it is important for South Africa to work together with the international community to identify a holistic approach to properly address the BEPS issues.

Consequently, modelling the guidelines and timeframe of the OECD on Action 13 in the final report and The Davis Tax Committee's (2014b) evaluation on Action 13, the Minister of Finance published changes to the $\mathrm{CbC}$ reporting standards for MNEs. These standards are specified in paragraph $(b)$ of the definition of 'international tax standard' in section 1 of the Tax Administrative Act, No. 28 of 2011 (TAA), promulgated under section 257 of the TAA (the SA CbC Regulations). The $\mathrm{SACbC}$ Regulations specify the changes to the $\mathrm{CbC}$ reporting standard for MNEs required for South Africa's circumstances and were published on 23 December 2016 in the Government Gazette (Republic of South Africa 2016). The Competent Authority of South Africa signed the Multilateral Competent Authority Agreement (MCAA) on the Exchange of Countryby-Country Reports on 27 January 2016, which is the implementing arrangement for the automatic exchange of $\mathrm{CbC}$ reports between South Africa and the other signatories of the CbC MCAA (SARS 2016).

The SA CbC Regulations were closely modelled on the model legislation related to the $\mathrm{CbC}$ reporting published in the final report (OECD 2015; SARS 2017a). The adoption of the model legislation, that is, the standardised approach, for the compilation of transfer documentation suggested by the OECD in the domestic legislation of South Africa leads to ambiguity regarding the interpretation and application thereof, which might influence the scope of $\mathrm{CbC}$ reporting, in a South African context. These ambiguities relate to the identification of a MNE Group and the determination of the total consolidated group revenue of that MNE Group.

Article 2 of the SA CbC Regulations sets the filing obligation, that is, the scope of $\mathrm{CbC}$ reporting which prescribes that each ultimate parent entity of an MNE Group that is resident for tax purposes in South Africa must file a $\mathrm{CbC}$ report if the total consolidated group revenue of that MNE Group is in excess of R10 billion (SARS 2016).

There seems to be no real consensus on how an MNE Group must be defined and total consolidated group revenue be determined for the purposes of $\mathrm{CbC}$ reporting in a South African context.

The remainder of this study is structured as follows:

- A discussion of the research objectives.

- The review identifying ambiguities that might influence the scope of $\mathrm{CbC}$ reporting in South Africa.

- The empirical analysis used to explore the impact of the identified ambiguities on Johannesburg Stock Exchange (JSE)-listed companies.

- Discussion of the results of the quantitative analysis.

- A summary and conclusion of the study. 


\section{Research objectives}

The primary objective of this study is to identify and address ambiguities that might influence the filing obligation and subsequent scope of $\mathrm{CbC}$ reporting in South Africa. The following research questions were developed from the primary objective:

- Must non-controlling entities be considered as Constituent Entities of an MNE Group?

- How should revenue be defined and interpreted?

- How significant is the effect of the identified ambiguities on business practice in South Africa?

\section{Review}

\section{The term 'Constituent Entity' as defined in Article 1 of the South African Country-by- Country Regulations}

Article 1 of the SA CbC Regulations provides an extensive definition of an MNE Group, including a definition of 'Group'. These definitions leave little room for uncertainty and can be summarised as a collection of enterprises, where two or more enterprises are tax residents in different jurisdictions, related through ownership or control such that it is required to prepare consolidated financial statements under applicable accounting reporting standards (SARS 2016).

Article 1 of the SA CbC Regulations defines consolidated financial statements as:

\begin{abstract}
... the financial statements of an MNE Group in which the assets, liabilities, income, expenses and cash flows of the Ultimate Parent Entity and the Constituent Entities are presented as those of a single economic entity. (SARS 2016:32)
\end{abstract}

The definition that might cause ambiguity regarding the identification of entities qualifying as group entities of an MNE Group is that of Constituent Entity. This definition is contained in Article 1 of the SA CbC Regulations and reads as follows:

\section{The term 'Constituent Entity' means}

(i) any separate business unit of an MNE Group that is included in the Consolidated Financial Statements of the MNE Group for financial reporting purposes, or would be so included if equity interests in such business unit of an MNE Group were traded on a public securities exchange;

(ii) any such business unit that is excluded from the MNE Group's Consolidated Financial Statements solely on size or materiality grounds; and

(iii) any permanent establishment of any separate business unit of the MNE Group included in (i) or (ii) above provided the business unit prepares a separate financial statement for such permanent establishment for financial reporting, regulatory, tax reporting, or internal management control purposes. (SARS 2016:30)

Ambiguity exists as to whether non-controlling entities, such as associates and joint ventures, should be included as a socalled Constituent Entity of an MNE Group for $\mathrm{CbC}$ reporting purposes.
When following this definition, one would have to determine whether the associated entity or joint venture is a separate business unit of the MNE Group included in the consolidated financial statements, as defined in the SA CbC Regulations or an MNE Group for financial reporting purposes.

In South Africa, IFRS 10 outlines the requirements for the preparation and presentation of consolidated financial statements. In order to be included in the consolidated financial statements of an MNE Group, the entities would have to be controlled entities in the MNE Group (IFRS 10 2011:par. 5-6).

Control implies that the parent has power over the investee, has exposure or rights to variable returns from its involvement with the investee and has the ability to use its power over the investee to affect the amount of the investor's returns (IFRS 10 2011:par. 5-6, par. 8).

If a parent entity has control over another entity, the parent should combine items of assets, liabilities, equity, income, expenses and cash flows of the parent with those of its subsidiaries to present the parent as a single economic entity (IFRS 10 2011:B86).

Where a parent entity has no control, but significant influence over an entity, such an investment represents a non-controlling interest. In practice, an investment of between $20 \%$ and $40 \%$ in another entity generally implies significant influence. A parent presents non-controlling interests in its consolidated statement of financial position within equity, separately from the equity of the owners of the parent (IRFS 10 2011:par. 22).

International Accounting Standard (IAS) 28 applies to all entities that are investors with joint control of, or significant influence over, an investee (associate or joint venture) (IAS 28 2011:par. 2). One of the objectives of IAS 28 is to set out the requirements for the application of the equity method when accounting for investments in associates and joint ventures (IAS 28 2011:par. 1).

Under the equity method, upon initial recognition the investment in an associate or a joint venture is recognised at cost and the carrying amount is increased or decreased to recognise the investor's share of the profit or loss of the investee after the date of acquisition (IAS 28 2011:par. 10). The total assets, liabilities, income, expenses and cash flows of the associate or joint venture are not presented together with those of the parent as a single economic entity, and therefore do not conform with the definition of Consolidated Financial Statements in Article 1 of the SA CbC Regulations.

SARS released an External Business Requirements Specification (BRS) on $\mathrm{CbC}$ and Financial Data Reporting as recently as 23 July 2017. In the BRS, SARS extends the definition of a Group by also including a collection of connected persons, as defined in section 1 read with section 31 of the Income Tax Act 58 of 1962 (the ITA) (the latter section regulating 
transfer pricing) (SARS 2017a). The definition of connected persons, as per section 1 read with section 31 of the ITA, can be summarised as follows: a company is a connected person in relation to another company that would form part of the same group of companies if the expression 'at least 70\%' (with reference to shareholding in the definition of a group of companies) was replaced by the expression 'more than $50 \%$ '. The first step is to determine the appropriate definition of a group of companies, and subsequently apply the 50\% exception to that definition to determine whether or not one complies with the first test of the 'connected person' definition.

The second test for a company in relation to another company is that the company will be a connected person if at least $20 \%$ of the equity shares in the company are held by that other company.

These two tests apply to circumstances where there is direct shareholding. Where there is no direct shareholding, a company will be a connected person in relation to another entity if such other entity is managed or controlled (more than $50 \%$ shareholding) by any person who or which is a connected person in relation to such company.

A group of companies is also defined in section 1 of the ITA as meaning two or more companies in which one company, the controlling group company, directly or indirectly holds shares in at least one other company, the controlled group company, to the extent that:

- at least $70 \%$ of the equity shares in each controlled group company are directly held by the controlling group company, one or more other controlled group companies or any combination thereof; and

- the controlling group company directly holds at least $70 \%$ of the equity shares in at least one controlled group company.

In relation to a company, a person is a connected person if a person individually or jointly with any connected person in relation to that person, holds, directly or indirectly, at least $20 \%$ of the equity shares or voting rights in the company.

Despite the fact that investments in associates and joint ventures are accounted for in the consolidated financial statements in terms of IFRS, it may be concluded that these types of non-controlling investments should not be considered as Constituent Entities of an MNE Group for CbC reporting purposes in South Africa.

In contradiction, based on domestic income tax legislation in South Africa, it may be concluded that investments in associates and joint ventures can, in fact, qualify as a connected person of a group with shareholding of at least $20 \%$. On this basis, these types of non-controlling investments should consequently be considered as Constituent Entities of an MNE Group for $\mathrm{CbC}$ reporting purposes in South Africa.
It therefore appears as if SARS requires information over and above what is contained in the modelled SA CbC Regulations. The conflicting views derived from the different regulations can prove problematic for MNEs when defining their MNE Group for $\mathrm{CbC}$ reporting purposes. The structure of an MNE Group is vital in the determination of the filing obligation, as only the aggregate revenue of Constituent Entities of the MNE Group should be measured against the revenue threshold.

\section{The interpretation of the concept 'revenue'}

The filing obligation and consequent scope of $\mathrm{CbC}$ reporting are dependent on the determination of the total consolidated group revenue of an MNE Group. The concept 'revenue' is not defined in the SA CbC Regulations, nor in the Guidance. Consequently, ambiguity exists as to which amounts should be regarded as revenue when considering the reporting threshold of R10 billion.

It is submitted that two possible interpretations exist. The first is derived from Article 2 of the SA CbC Regulations, the filing obligation regulation, and refers to the total consolidated group revenue of an MNE Group (as defined in 'The term Constituent Entity, as defined in Article 1 of the SA CbC regulations' section - second paragraph).

The latter implies that the amount of revenue must be determined with reference to the governing accounting principles regulating the measurement and recognition of revenue in the jurisdiction of the filing entity of the MNE Group. This view is supported by the Guidance, in which the OECD refers to total consolidated group revenue as items that are included in total consolidated group revenue if those items are presented in the consolidated financial statements under the applicable accounting rules of the jurisdiction in which the filing entity is a tax resident (OECD 2017).

IFRS 15, the accounting principles applicable to revenue in South Africa, defines revenue as 'income that arises in the course of an entity's ordinary activities'. Income is a broader term which encompasses revenue and is defined as:

\footnotetext{
... increases in economic benefits during the accounting period in the form of inflows or enhancements of assets or decreases of liabilities that result in an increase in equity, other than those relating to contributions from equity participants. (IFRS 15 2014:Appendix A)
}

To be classified as revenue, income must therefore derive from ordinary activities.

The concept 'ordinary activities' is not defined in IFRS. The Oxford Dictionary of Accounting (Law 2010) defines the term as 'activities that are usually, frequently or regularly undertaken by the entity or a related activity engaged in by the entity in furtherance of, incidental to, or arising from activities usually, frequently or regularly undertaken by it'. Hence, in practice, companies normally disclose revenue generated from their core business activities as a separate line 
item from which cost of sales is deducted to derive a figure for gross profit. Amounts received from activities other than core business activities are disclosed as other income.

The second interpretation of the concept of revenue in the context of $\mathrm{CbC}$ reporting is derived from the standard template set out in the OECD's final report on BEPS Action 13, Transfer Pricing and $\mathrm{CbC}$ reporting. Article 4 of the $\mathrm{SA} \mathrm{CbC}$ Regulations prescribes that the $\mathrm{CbC}$ report must contain the information set out in, and apply the definitions and instructions contained in, the standard template in Annex III to Chapter V of the final report.

The final report includes revenues from sales of inventory and properties, services, royalties, interest, premiums and any other amount, but excludes payments received from other constituent entities that are treated as dividends in the payer's tax jurisdiction (OECD 2015). This description seems to refer to the concept of income rather than revenue, but, for example, does not include foreign exchange gains.

The BRS remains silent on the interpretation of the concept when referring to revenue (SARS 2017b). Interaction with practitioners showed that they are of the opinion that the outline as per the Guidance of what should be reported as revenue should also be applied to determine the total consolidated group revenue of an MNE Group, against which to measure the R10 billion threshold. This view is, however, in contradiction with the meaning assigned to the concept of revenue as per IFRS 15, as determined with reference to the SA CbC Regulations.

The contradictory views regarding the determination of revenue to determine the threshold and subsequent filing obligation may influence the scope of $\mathrm{CbC}$ reporting in a South African context. The significance of the impact of the identified ambiguities relating to both constituent entities and revenue was investigated and described in the next section.

\section{Empirical analysis Background}

In the 'Review' section, reference was made to relevant legislation, terms used therein, international standards and further applicable literature. The ruling in CIR $v$. Stellenbosch Farmers' Winery 13 SATC 381 determined that, in South Africa, the accounting treatment of amounts does not necessarily determine the tax consequences thereof. The $\mathrm{CbC}$ reporting regulations are effectively provisions prescribing and administering the reporting of information from an international tax point of view. The fact that the terminology in the SA CbC Regulations is based on those provided by the OECD, which appears to be driven by accounting, rather than tax principles, justifies the analysis of applicable IFRSs in this study.

The outcome of the review forms the theoretical basis of the empirical analysis by identifying ambiguities that might influence the scope of $\mathrm{CbC}$ reporting in a South African context.
As discussed, $\mathrm{CbC}$ reporting is only applicable to MNEs with a group revenue in excess of R10 billion. For each of these prerequisites, that is, (1) an MNE Group (2) revenue, ambiguity exists in conflicting definitions.

First of all, to be categorised as an MNE Group, IFRS requires that the entity must have at least one foreign subsidiary as opposed to SARS that requires having at least one of a foreign subsidiary, associate or joint venture. For the purpose of this study, the former is called the narrow MNE Group definition and the latter the wider MNE Group definition.

In addition, revenue can either be defined as revenue as calculated in terms of IFRS or the revenue line items plus income, as determined by IFRS. In a similar vein, the former is called the narrow revenue definition and the latter the wider revenue definition.

\section{Defining the study population}

To answer the research questions, this study required financial data from JSE-listed companies. Based on a list received from the JSE, there were 293 companies listed with ordinary shares on the JSE main board on 31 December 2016 (excluding suspended companies). Given the information needs of this study, 215 companies were removed as summarised in Table 1 and discussed below.

As a first step, the 101 companies listed in the financial industry were removed given their unique financial reporting structure (e.g. interest income instead of revenue) and additional disclosure requirements. Another three companies were removed as these companies did not publish a 2016 annual report and no financial statement data were therefore available for 2016.

The authors further argued that as companies with an IFRS reported revenue of less than R8 billion (i.e. narrow definition) were not at risk of misclassification if the wider definition is used, all companies with a reported revenue of less than R8 billion were removed. Another 108 companies were therefore removed.

Finally, as $\mathrm{CbC}$ reporting is only applicable to companies with at least one foreign subsidiary (narrow MNE Group definition) or at least one foreign subsidiary or associate or joint venture (wider MNE Group definition), three companies were removed as these companies had neither a foreign subsidiary, associate nor joint venture and could therefore

\section{TABLE 1: Defining the study population.}

\begin{tabular}{lc}
\hline Detail & Number \\
\hline $\begin{array}{l}\text { Companies listed with ordinary shares on the Johannesburg Stock } \\
\text { Companies listed in the financial sector }\end{array}$ & 293 \\
Companies that did not publish a 2016 annual report as on 31 July 2017 & -101 \\
Companies with revenue less than R8 billion (narrow definition) & -3 \\
Companies with no foreign subsidiaries, associates or joint ventures & -3 \\
Study population & 78 \\
\hline
\end{tabular}


not be classified as an MNE Group. The result is a study population of 78 companies.

\section{Methodology}

To ascertain whether the conflicting revenue and MNE Group definitions, as discussed, have a significant impact on business practice in South Africa, a two-stage methodology is followed. Firstly, the group structure of the study population is inspected to establish the impact of using respectively the narrow and the wider MNE Group definition.

Secondly, the 2016 annual reports ${ }^{1}$ of the study population are scrutinised to ascertain the bearing of using, respectively, the narrow and the wider revenue and MNE Group definitions. To ascertain the significance of the impact of the various definitions on revenue and therefore whether the company is $\mathrm{CbC}$ compliant or not, $t$-tests were performed to determine whether companies' reported revenue (narrow definition) differs significantly from firstly revenue (wider definition) using the narrow MNE Group definition and secondly revenue (wider definition) using the wider MNE Group definition.

Based on an inspection of the normal $p$-plot of the revenue (narrow definition), revenue closely resembles a normal distribution (an assumption that is needed for using the $t$-test [Keller \& Warrack 1997]).

\section{Data collection}

Revenue (narrow definition) and group structures were captured from the IRESS database (previously known as INET BFA). To calculate revenue (wider definition) and to confirm the multinational status of companies with no foreign subsidiaries according to IRESS, the 2016 annual reports of companies were used. The effective date of the $\mathrm{CbC}$ Reporting Regulations in South Africa was year-ends ending on or after 31 December 2016. As such, the 2016 calendar year was seen as the turning point for this research.

\section{Results}

Results are discussed with reference to the two-stage methodology followed in this study (see the 'Methodology' section).

\section{Stage 1}

Of the 78 companies in the study population (see Table 1), two companies did not have a foreign subsidiary, but their 2016 annual report did include at least one foreign associate or joint venture. Using the narrow MNE Group definition 76 companies therefore qualify as opposed to the wider MNE Group definition where 78 companies qualified. Table 2 summarises these results.

1.The SA CbC Regulations apply with effect from the reporting fiscal years of MNE Groups beginning on or after 01 January 2016 and, consequently, a qualifying South African-parented group with a calendar financial year will be expected to file its first report for 2016 with SARS by the end of 2017 (SARS 2016).
TABLE 2: Multinational enterprise group categorisation - narrow versus wider multinational enterprise group definition.

\begin{tabular}{lcc}
\hline Detail & \multicolumn{2}{c}{ Number } \\
\cline { 2 - 3 } & $\begin{array}{c}\text { Narrow MNE } \\
\text { group }\end{array}$ & $\begin{array}{c}\text { Wider MNE } \\
\text { group }\end{array}$ \\
\hline $\begin{array}{l}\text { Study population (see Table 1) } \\
\begin{array}{l}\text { Companies with no foreign subsidiaries, but at least } \\
\text { one foreign associate or joint venture }\end{array}\end{array}$ & 78 & 78 \\
MNE Group & 76 & N/A \\
\hline
\end{tabular}

MNE, multinational enterprise; N/A, not applicable.

TABLE 3: Comparison of alternative revenue definitions for companies with a revenue (narrow definition) more than R8 billion, but less than R10 billion.

\begin{tabular}{lc}
\hline Revenue & $\begin{array}{c}\text { Number of companies } \\
\text { with revenue exceeding } \\
\text { R10 billion }\end{array}$ \\
\hline Narrow definition & 0 \\
Wider definition (excluding associates and joint ventures) & 3 \\
Wider definition (including associates and joint ventures) & 4 \\
\hline
\end{tabular}

\section{Stage 2}

Of the above 78 companies included in the study population, 13 companies had a reported revenue of less than R10 billion, but more than R8 billion according to the narrow definition. However, if the wider revenue definition is including, for example, other income and interest received, but excluding the companies' profit share from associates and joint ventures, 3 of the 13 companies will now have a revenue figure exceeding R10 billion. Including the companies' profit share from associates and joint ventures, based on the wider MNE Group definition, 4 of the 13 companies will have a revenue figure exceeding R10 billion.

Table 3 shows the number of companies that will have to comply to $\mathrm{CbC}$ reporting if either of the two wider definitions is used.

Although it is admitted that the power of statistical tests will be severely restricted given the small number of companies, $t$-tests were performed to test whether the groups (based on revenue definitions) as reported in Table 3 differed significantly from each other.

The revenue (narrow definition) group differed significantly from both the wider definition groups at, respectively, the $1 \%$ level $(p=0.006)$ for the revenue wider definition group excluding associates and joint ventures and the 5\% level ( $p=0.039)$ for the revenue wider definition group including associates and joint ventures.

These results therefore provide some statistical evidence that the ambiguities in defining MNE group constituents and revenue, as discussed in this article, has a significant impact on business practice. Whether companies will have to comply or be exempted from $\mathrm{CbC}$ reporting may therefore depend on whether the wider or narrow definitions are used for both revenue and MNE group constituents.

\section{Conclusion and recommendations}

The OECD's objective with Action 13 of the BEPS initiative was to create a global standard for $\mathrm{CbC}$ reporting, enabling data to be easily shared and compared by tax authorities 
when undertaking transfer pricing risk assessments. The inconsistent and uncoordinated implementation of the BEPS recommendations on Action 13 in South Africa may lead to failure to implement, or defaulting on, South Africa's international commitments. Such failure or defaulting may result in a public non-compliant rating of South Africa, which will result in other countries not being willing to exchange information with South Africa. Such an outcome may have an adverse impact on other international ratings.

Therefore, the objective of this study was focussed on the identification of the filing obligation and subsequent scope of $\mathrm{CbC}$ reporting in South Africa. The review identified possible obstacles a South African MNE Group may face while determining whether they must comply with the $\mathrm{CbC}$ reporting documentation rules. The analysis of the terms Constituent Entity and Group indicated that as a result of the influence of South African domestic income tax legislation, the structure of MNEs is defined more broadly than that of the global standard by also including non-controlling entities like associates and joint ventures as Constituent Entities. The analysis of the concept 'revenue' indicated that two possible interpretations of the concept exist. The concept can either be interpreted by means of IFRS 15 to equate to income generated from transactions from the 'ordinary activities' of the entity or be interpreted through the much wider outline of revenue that must be disclosed as per the OECD.

A quantitative analysis to explore the impact of conflicting MNE Group and revenue definitions, provided support for need for more precise guidance to companies on whether they have to comply. A comparison of the conflicting revenue definitions provides a compelling case for guidance on how revenue should be defined, as 4 of the 13 companies with a reported revenue between $\mathrm{R} 8$ and $\mathrm{R} 10$ billion face the risk of misclassification depending on the definition used.

It should however be emphasised that it can merely be concluded that the application of alternative revenue definitions has a significant impact on the revenue amount of companies with a reported revenue (i.e. narrow definition) of between R8 and R10 billion. Care should be taken that these findings are not generalised to conclude that a change in classification (i.e. whether the company is $\mathrm{CbC}$ compliant or not) is statistically expected, as such a reclassification also depends on the reported revenue before the application of the alternative revenue definitions (e.g. a company with a reported revenue of $\mathrm{R} 8$ billion compared to a company with a reported revenue of $\mathrm{R} 9.9$ billion).

The exclusion of companies with a reported revenue of less than $\mathrm{R} 8$ billion can be seen as a possible limitation, as these companies may have significant amounts of other income and/or foreign associations and joint ventures. A further limitation may be the exclusion of companies listed in the financial sector. This warrants the need for future research through an application of a wider definition of the study population; for example, including companies with a reported revenue of less than $\mathrm{R} 8$ billion or companies listed in the financial sector. This study further focussed only on pointing out ambiguities, with no attempt to rectify such ambiguities. Future research could therefore focus on how $\mathrm{CbC}$ compliance should be defined in an international context.

\section{Acknowledgements}

The authors would like to thank the two anonymous reviewers for their time and input, which has been most helpful in refining and improving this article. The authors sincerely believe that the revised article is of a much higher standard after the recommended changes.

\section{Competing interests}

This is a declaration to confirm that the views expressed in this article are those of the authors and that they have no financial or personal relationships that may have inappropriately influenced them in writing this article.

\section{Authors' contributions}

The review identifying the ambiguities regarding the filing obligation and subsequent scope of country-by-country reporting in South Africa was performed by the corresponding author (C.T.). The measurement of the potential impact of the identified ambiguities in business practice, through the quantitative analysis, was performed by the second author (G.F.N.).

\section{References}

CIR v Stellenbosch Farmers' Winery [1945] 13 SATC 381.

IAS 28, Investments in Associates and Joint Ventures, 2011, International Accounting Standards Board (IASB), London, viewed 05 February 2017, from https://www. iasplus.com/en/standards/ias/ias28-2011

IFRS 10, Consolidated Financial Statements, 2011, International Accounting Standards Board (IASB), London, viewed 05 February 2017, from https://www.iasplus.com/ en/standards/ifrs/ifrs10

IFRS 15, Revenue from Contracts with Customers, 2014, International Accounting Standards Board (IASB), London, viewed 05 February 2017, from https://www. Standards Board (IASB), London, views/ifrom/en/standards/ifrs 15
iasplus.com

Keller, G. \& Warrack, B., 1997, Statistics for management and economics, 4th edn., Duxbury Press, Pacific Grove, CA

Law, J. (ed.), 2010, Oxford Dictionary of Accounting, Oxford University Press, Aylesbury. http://doi.org/10.1093/acref/9780199563050.001.0001

National Treasury, 2017, Budget speech by Minister of Finance, viewed 24 February 2017, from http://www.treasury.gov.za/documents/national\%20budget/2017/ speech/speech.pdf

OECD, 2010, OECD transfer pricing guidelines for multinational enterprises and tax administrations, OECD Publishing, Paris, viewed 19 June 2017, from http://www. administrations, OECD Publishing, Paris, viewed 19 June 2017, from http://wWW.
keepeek.com/Digital-Asset-Management/oecd/taxation/oecd-transfer-pricingkeepeek.com/Digital-Asset-Management/oecd/taxation/oecd-transfer-pricing-
guidelines-for-multinational-enterprises-and-tax-administrations-2010_tpg-2010guidelines-for-
en\#page4

OECD, 2013, Action plan on base erosion and profit shifting, OECD Publishing, Paris, viewed 05 February 2017, from https://www.oecd.org/ctp/BEPSActionPlan.pdf

OECD, 2015, Transfer pricing documentation and country-by-country reporting, action 13 - 2015 final report, OECD Publishing, Paris. https://doi.org/10.1787/9789264 241480-en

OECD, 2017, Guidance on the implementation of country-by-country reporting - BEPS action 13, OECD Publishing, Paris, viewed 20 June 2017, from http://www.oecd. org/tax/beps/guidance-on-the-implementation-of-country-by-country-reportingbeps-action-13.htm

Republic of South Africa, 1962, Income Tax Act 58 of 1962, Government Printer, Pretoria. Republic of South Africa, 2011, Tax Administration Act 28 of 2011, Government Printer, Pretoria.

SARS, 2016, 'Regulations for purposes of paragraph (b) of the definition in "International Tax Standard" in section 1 of the Tax Administration Act, 2011 (Act no. 28 of 2011), promulgated under section 257 of the Act, specifying the changes to the Countryby-Country Reporting Standard for Multinational Enterprises', viewed 30 January by-Country Reporting Standard for Multinational Enterprises, viewed 30 January Reg-2016-07\%20-\%20Regulation\%20R1598\%20GG40516\%20-\%2023\%20 Reg-2016-07\%20-\%20R
December\%202016.pdf 
SARS, 2017a, Draft public notice requiring the submission of CbC, master file and local file returns, viewed 23 June 2017, from http://www.sars.gov.za/AllDocs/LegalDoclib/ Drafts/LAPD-LPrep-Draft-2017-27\%20-\%20Draft $\% 20$ public $\% 20$ notice $\% 20$ requiring $\% 20$ the $\% 2$ submission $\% 20$ of $\% 20 \mathrm{CbC} \% 20$ master $\% 20$ file $\% 20$ and $\% 20$
local $\% 20$ file $\% 20$ returns.pdf

SARS, 2017b, External business requirements specification: Country-by-country and financial data reporting, viewed 23 June 2017, from http://www.sars.gov.za/
AllDocs/LegalDoclib/Agreements/LAPD-IntA-EIA-CBC-2017-03\%20-\%20Final\%20 BRS $\% 20$ on $\% 20$ the $\% 200$ ECD $\% 20$ CbC $\% 20$ Reporting.pdf
(The) Davis Tax Committee, 2014a, Davis Tax Committee Interim Report: Addressing base erosion and profit shifting in South Africa, viewed 02 March 2017, from http://www.taxcom.org.za/docs/New Folder/1\%20DTC\%20BEPS\%20 Interim\%20Report\%20-\%20The\%20Introductory\%20Report.pdf

(The) Davis Tax Committee, 2014b, Davis Tax Committee Interim Report: Addressing base erosion and profit shifting in South Africa. Action 13: Re-examine transfer pricing documentation, viewed 02 March 2017, from http://www.taxcom.org.za/docs/New Folder $/ 7 \% 20$ DTC $\% 20$ BEPS $\% 2$ Interim $\% 2$ Report $\% 20$ on $\% 20$ Action $\% 20$ Plan $\% 2$ $13 \% 20 \% 20$ Transfer $\% 20$ Pricing $\% 20$ Documentation, $\% 202014 \% 20$ deliverable.pdf 